it might be accomplished, I dispatched a messenger to $\mathrm{Ge}_{n}$ eral Blunt to inform him of what I was doing, and hastily threw my line up into the dense timber on my right, twice its own length, and then pushed it steadily forward.

[TO BE CONTINUED.]

INDIAN OOURTSHIP AND WHITE WEDDINGS.

BY HAWKINS TAYLOR, WASHINGTON, D. C.

T the day of Blackhawk's disgrace, after the Blackhawk 1 war, and before we had got sufficiently civilized to try by court martial and shoot the savages, before the days of furnishing the Indians tin hoes, spades, and other implements of husbandry to learn them to be farmers, before the system of robbing them had become a science as now, the government took all power and authority in the tribe from Blackhawk and his followers. After their murders and the war that followed, the effect was that there has been harmonious peace with the tribes since. To Blackhawk it was far worse than death. After the war, up to his death, he wintered and his wife and daughter made sugar on Devil creek, in Lee county. His wigwam was large for an Indian's, and was always kept in perfect order. It was a few hundred yards from the creek, and about one hundred yards above the old Fort Madison and Montrose road, on the Fort Madison side of the creek. I often stopped at the camp 
and bought little cakes of singar from the wife and daughter. It was clean and very nice. The old lady was neat, for an Indian. The daughter was very neat and handsome, small, but finely formed; but mother and daughter appeared to be thoroughly broken down in hope and feeling, and it was a truly sad sight to see them in their mournful, lonely condition. I imagine that few kings ever lost their crown with more regret and mortification than did Blackhawk and his family. I could not but feel great interest in the two women. There was no pretense about them; everything neat, resigned, and real.

Among the first merchants at Fort Madison was a young man by the name of ${ }^{\prime} W$ alsh, from Baltimore, Maryland, a young man of polished education and manners, and of one of the oldest and wealthiest families of Baltimore. I do not know what induced him to go to that wild country; probably some wild romance. He had his store in what was then called "Lower Fort Madison," in what is the center of the town now, but then a wilderness of heavy timber and pea-vines higher than your head. There were probably twenty shanties, all told, on Front street, in the lower part of town, mostly rum-shops. Walsh had the only store The customers were emigrants, going to the country back, and Indians. Among the Indians was Mrs. Blackhawk and her daughter. Walsh had been there solitary long enough for the romance of a new country to wear off to a very thin veneering. He was sad and wanted sympathy. Miss Blackhawk was very handsome, of her class. She was a fallen queen, looked it and felt it. She, like Walsh, wanted sympathy and association. Walsh had acquired the Indian language, so that he could talk with her in her own tongue. An intimacy soon grew up. Walsh would go and spend his Sundays at Blackhawk's. From going on Sundays he soon got to locking up and leaving. his store, and go and stay several days at a time. He cared little about money, not needing it, and he had no associates that he cared for amongst his white neighbors. He wrote to St. Louis to his 
cousin, a wholesale grocer in that city, that he was going to marry Miss Blackhawk, and gave a most glowing account of her beauty, goodness, and intellect. His cousin went at once to see him, and went with him to see Miss Blackhawk. He appeared to be delighted with her, and with apparent cheerful earnestness entered into the arrangements for the wedding. He spent several days at Walsh's store, each evening riding down with him to Blackhawk's.

One evening when they were talking over the matter, after their return from Blackhawk's, and but a few days before the wedding was to be, "Edgar said to Walsh: "Jo, there is but one thing about this whole business that troubles me, and I have been studying how to overcome it." "What is that?" "Why, when you get married you must take your wife to see our people, and in Baltimore, as you know, there is a miserable rabble, and an Indian is to them a great curiosity. When you go into the street they will raise the cry, 'There goes Jo 'Walsh's Indian.' They will not know of the good noble qualities of your wife, and will not care. This must be overcome in some way."

Edgar, in telling me about it afterwards, said he never saw anything affect a man as his words affected Walsh, but not another word was said. The next morning when they got up, Walsh said that if he could sell his store he would go back to Baltimore. Edgar asked him what he wanted for the store. Walsh named a price, and Edgar took it at the price, and the next boat down the river took Walsh on his way back to Baltimore. Edgar sold out the store for what he could get for it and went back to St. Louis, and Walsh went to Baltimore. Edgar's tactics succeeded, when, to have adopted the usual method of breaking off matches, would have failed. Miss Blackhawk married a clever Indian, and was respectable as Indian respectability goes. Of Walsh I know nothing, since he went to Baltimore.

For many years in the early days of Iowa, Squire Bedell, who lived a few miles above St. Francisville, on the $\checkmark$ Des Moines river, was the Gretna Green for all southern 
Iowa. No license was then required in Missouri to author ize a justice of the peace to solemnize matrimony. All that was required was for the justice to make a return to the county court of the fact. This was sometimes done, but often neglected. 'Bedell was a rough, early settler, and did a large business in the marrying line. Some went to him to save expense, others for the fun of it, and others again to escape from the parental wrath. Bedell was always on the look-out, and the moment that he saw a couple approach. ing on the other side of the river, he would man his boat and cross the river to meet them. On one occasion the river was full of floating ice, on the Missouri side, but the ice bore the matrimonially inclined couple from the Iowa side to the middle of the river. Bedell said that would do, and married them, standing on shore and they on the middle of the river on the ice, the squire loosing his fee, and the pair loosing the usual treat always provided by the squire. Bedell said that there was not much pay in the thing, but a great deal of fun.

\section{"HISTORY OF OIVILIZATION."}

LBy Amos Dean, LL. D, late professor in the Medical College and Law School of the University of Albany, and first chancellor of the University of Iowa. In seven volumes, octavo, $\$ 21.00$ a set, payable on delivery. Published and sold by Joel Munsell, Albany, N. Y.]

THIS work is the result of thirty-five years of unremitting 1 research and study. It is both an encyclopedia and philosophy of history, containing a greater amount and variety of matters interesting and important to be known than any other history of like size in the English language.

It is a record of human progress, studied- 
Copyright of Annals of Iowa is the property of State of Iowa, by \& through the State Historical Society of Iowa and its content may not be copied or emailed to multiple sites or posted to a listserv without the copyright holder's express written permission. However, users may print, download, or email articles for individual use. 